UDC 622.23.05.: 65.011.4

T. Olejarz ${ }^{1}$, Cand. Sc. (Hist.), Assoc. Prof., orcid.org/0000-0001-7940-3248,

V. Nitsenko ${ }^{2}$, Dr. Sc. (Econ.), Assoc. Prof., orcid.org/0000-0002-2185-0341,

O. Chukurna ${ }^{3}$, Cand. Sc. (Econ.), Assoc. Prof., orcid.org/0000-0001-9285-7068,

M. Mykhailova ${ }^{4}$, Cand. Sc. (Econ.), Assoc. Prof.,
DOI: $10.29202 / \mathrm{nvngu} / 2018-1 / 2$

1 - Rzeszow University of Technology, Rzeszow, Poland, e-mail: olejarz@prz.edu.pl

2 - Odessa I. I. Mechnikov National University, Odessa, Ukraine, e-mail: vitaliinitsenko@gmail.com

3 - Odessa National Polytechnic University, Odessa, Ukraine, e-mail: elenchukurna@ukr.net

4-Kharkiv State University of Food Technology and Trade, Kharkiv, Ukraine, e-mail: mvmykhailova@gmail.com

\title{
EVALUATION OF FACTORS INFLUENCING LABOUR PERFORMANCE OF MACHINE-BUILDING ENTERPRISES IN MINING INDUSTRY
}

Т. Олеяж ${ }^{1}$, канд. іст. наук, доц., orcid.org/0000-0001-7940-3248,

В.С. Ніценко ${ }^{2}$, д-р екон. наук, доц., orcid.org/0000-0002-2185-0341,

О.П. Чукурна ${ }^{3}$, канд. екон. наук, доц., orcid.org/0000-0001-9285-7068,

М. В. Михайлова ${ }^{4}$, канд. екон. наук, доц.
$1-$ Жешувський технологічний університет, м. Жешув, Польща, e-mail: olejarz@prz.edu.pl

2 - Одеський національний університет імені I. I. Мечникова, м. Одеса, Україна, e-mail: vitaliinitsenko@ gmail.com 3 -Одеський національний політехнічний університет, м. Одеса, Україна, e-mail: elenchukurna@ukr.net 4 -Харківський державний університет харчування та торгівлі, м. Харків, Україна, е-mail: mvmykhailova@ gmail.com

\section{ОЦІНКА ФАКТОРІВ ВПЛИВУ НА ПРОДУКТИВНІСТЬ ПРАЦІ МАШИНОБУДІВНИХ ПІДПРИЕМСТВ ГІРНИЧОДОБУВНОЇ ПРОМИСЛОВОСТІ}

Purpose. The article is devoted to the investigation of factors influencing labour productivity of machine-building enterprises in mining industry and to their evaluation in order to increase the competitiveness. To develop ways to increase the competitiveness of engineering enterprises within the same mining industry by the means of increasing their labour productivity. To determine the relationship between labour productivity at engineering enterprises of mining industry and return on assets as well as return on sales using correlation analysis. To ground and to explain the indicator of labour as basis for the formulation of quantitative and qualitative indicators used in further assessment of production competitiveness at machine-building enterprises.

Methodology. The study uses the methods of analysis and synthesis, deduction and induction (in determining the factors affecting company's productivity), systematization and generalization (to clarify the relationship between living and materialized labour, to suggest new ways to increase productivity and, thus, enhance enterprises' competitiveness), correlation analysis (in determining the relationship between labour productivity at machine-building enterprises of mining industry and the indicators of return on assets and return on sales).

Findings. Impacts on productivity of machine-building enterprises within the mining industry are analysed and explained. Forms of labour productivity are investigated on the sample of these enterprises. Ways for further improvement are determined concerning the increased productivity of these enterprises that are producing equipment for the mining industry which include: improving the organization of production and labour through formation of labour force possessing newest qualifications; transformation of factors of macroeconomic environment of these enterprises, especially those of ecological sphere; structural transformation of production, aimed at modernization of fixed assets; creation and development of necessary social infrastructure; ensuring business competitiveness based on the definition of marginal productivity. The authors suggest new directions of increasing enterprises' competitiveness through implementation of following measures: revision of the key competitive strategies; increase in revenue through higher prices and raised marketing spendings; cost cutting; reduction of illiquid assets; combining all these methods from above. It is also recommended to ensure these enterprises' competitiveness on the basis of determining their marginal productivity. The degree of influence of return on assets and sales margins on productivity of machine-building enterprises within the mining industry is established using correlation analysis.

Originality. The level of labour productivity is economically grounded through the use of both quantitative and qualitative indicators directed on the measurement of the competitiveness of machine-building enterprises. An approach is presented which is supposed to ensure the competitiveness of enterprise-based marginal productivity based on defining production volume growth using an additional unit of labour under other fixed conditions. This approach encourages enterprises optimizing their resources through the application of additional labour or displacement of inefficient work and reaching optimal marginal productivity. 
Practical value. The results of this research can be used for further development both in scientific and practical ways. Thus, they can be used by machine-building enterprises as an element of improving the competitiveness economically based on the labour productivity index. A new approach is presented here which uses the reduction of time needed for market circulation of products or logistics cycle, directly related to the time saving. As a result, enterprise resources reach higher productivity which is occurring due to the increasing asset value and the performance metrics concerning the return on company's sales.

Keywords: machine building, labour productivity, competitiveness, return on assets, return on sold products

Introduction. Labour productivity is one of the indicators of the productivity. The growth of labour productivity serves as the means for lowering production costs and increasing the enterprise profits. In general, labour productivity growth should form the reserves for the creation of price advantages at industrial markets.

The overall competitiveness of the company is based on the price and quality advantages of the enterprise in industry. However, labour productivity, as an economic indicator, is a common source of their formation. Thus, the economic nature of the productivity is based upon quantitative and qualitative factors of its formation. The competitiveness of industrial and machine-building companies in the B2B market is of specific interest. The development of machine-building enterprises in the mining industry of Ukraine has quite capacious potential. According to experts, the explored reserves of iron ore only amounted to 32.5 billion tons in Ukraine, $70 \%$ of which are lying in Kryvyi Rih iron ore basin. In addition, Ukraine has significant reserves of coal, uranium and manganese ores that are actively mined, which requires special equipment and should contribute to the development of machine-building enterprises of mining industry. Under these conditions, the study of factors influencing the productivity of the machine-building enterprises in mining industry and their assessment in relation to the recent World trends in this field become particularly relevant.

Analysis of the recent research and publications. Many Ukrainian scholars-economists have investigated the problems of industry economics, including those of the enterprises of mechanical engineering. Famous Ukrainian scientists detail the economic problems of the development of industrial enterprises and the influence of various factors on them. For example, O. I. Amosha, L. L. Starychenko and D. Yu. Cherewatsky [1] point out the problems and prospects for the development of the coal industry and determine the profitability of the industry, but do not investigate its impact on the development of machine-building enterprises in mining industry. In turn, I. P. Buleev, N. Yu. Bryukhovetska [2], S. Chuprov [3], M. Puziak [4], V. I. Lyashenko [5], R. O. Dychkovskyi, A. S. Avdiushchenko, V. S. Falshtynskyi, P. B. Saik [6], G. G. Piwniak, V. I. Bondarenko, V. I. Salli, I. I. Pavlenko, R. O. Dychkovskiy [7], define the growing economic problems of industry and propose their solution via mobilization of domestic resources of the country and attraction of capital and advanced technologies. They believe that the principles of institutional theory of society development should be used as the basis for the industry reform. Much attention is paid to the creation of proper institutes for the formation and implementation of Ukraine's economic policy.

Unsolved aspects of the problem. Despite the significant contribution of scientists to the study of the eco- nomics of industry, the question of the impact of economic factors on labour productivity has been studied insufficiently. In scientific works devoted to the economic problems of the development of machine-building enterprises, scientific issues have not been sufficiently investigated. Their purpose should have been to substantiate labour productivity as the basic indicator of increasing the competitiveness of industrial enterprise. All the above aspects show the relevance of current paper and the need to use its results in further scientific research.

The object of the article is to evaluate factors influencing productivity of machine-building enterprises in the mining industry in order to improve their competitiveness.

Presentation of the main research and explanation of scientific results. Labour productivity is measured by summing up consumer values created per unit time or the required time spent per unit labour product. Labour productivity, as an economic indicator, is measured by the amount of product produced by one employee during certain period of time or during unit of time.

In the economic theory there are two approaches to the interpretation of the concept of productivity. The first considers the productivity of human labour, which is determined by the cost of work used in the production of this product. The second approach offers to assess aggregate productivity of social labour, measuring it by total costs of living and materialized labour. Increased productivity is connected to the decrease in living labour with the respective increase in materialized labour. In this way the proportion of labour in product is reduced. This is due to more rapid decrease in living labour than the growth of materialized labour. The cumulative saving of working time is achieved by reducing the resource costs of production, which in turn characterizes efficiency.

At the micro level, meaning at the enterprise level, labour productivity is measured as an output per employee or per unit of time. At this level, the indicator of efficiency considers only economy of the manpower. At the macro level, labour productivity is measured by the ratio of the physical volume of national income to the number of employees in material production. Thus, labour productivity is the indicator reflecting directly the savings of human labour at the micro level and indirectly the savings of social labour via the volume of national income at the macro level.

In order to understand the economic essence of productivity it is necessary to consider the forms of its manifestation.

The first form of manifestation of labour productivity is the reduction of labour costs per unit of consumer value and the economy of working time. The most important is the absolute reduction in labour costs necessary to meet a certain social need. This approach to the abso- 
lute reduction of labour costs is forcing companies to use the ways to save labour and material resources.

Another form of productivity display is the growth of the mass consumer values that are generated per unit of time. Considering the indicator of labour productivity in this respect, it is necessary to take into account not only the volumes of manufactured goods, but also the increase in their quality. This approach is based on the fact that the creation of consumer value needs a specific work to be done that, in turn, reflects the public value of the product. Respectively, the value of goods depends on the set of consumer properties, which are the basis of product quality and form its ability to meet the needs of consumers.

Therefore, on practice the consideration of this approach to the productivity manifestation implies its widespread use in assessing the product usefulness or value.

In this respect, labour productivity forms qualitative indicators for assessing the competitiveness of industrial enterprises. That is why labour productivity embodies competitiveness of the enterprise. In this context, let us consider the development of Ukrainian mining industry, which is characterized by too low labour productivity indexes, which have a tendency to a sharp decline in the area of machine-building (Fig. 1).

Fig. 1 shows a decline in labour productivity in machine-building industry by almost 8 times only in 2011 , with a gradual decline during 2012-2016. The development of the machine-building industry, especially that of the mining industry, depends, respectively, on the developments of the mining industry itself. Labour productivity of the latter has been also rapidly decreasing, starting since 2009. Thus, machine-building industry was lagging 2 years to the change in the efficiency of the mining industry.

If we consider labour productivity of the machinebuilding enterprises that produce equipment and mechanisms for the mining industry, then it becomes apparent that this indicator is higher than the average one in the mechanical engineering industry (Fig. 2).

The highest level of labour productivity is observed at PJSC "Novokramatorsky machine-building plant". PJSC "Odesa Machine Building Plant" also has a high labour productivity index, which experienced a significant drop in 2014, but later this crisis had been overcome. The producer of the mining equipment PJSC "Kholmodmash" also has a performance indicator higher than the average one, although it is the lowest among the enterprises that were considered. Thus, PJSC "Novokram-

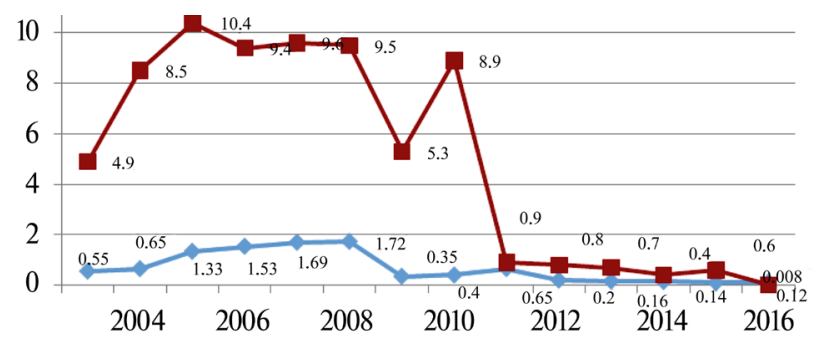

Fig. 1. Dynamics of changes in labour productivity in machine-building and mining industries in 2003-2016: $\rightarrow-$ labor productivity in the mining industry; $\rightarrow--$ labor productivity in machine-building industry atorsky Machine-Building Plant" has the highest rate of output per worker. Accordingly, each worker of the enterprise creates the largest consumer value of the product, which is produced per unit of time. It can be concluded that despite the overall decline of this indicator in industry, mining engineering machinery industry remains quite popular. This is explained by the fact that raw material orientation of industry persists in Ukraine, despite the fact that starting since 2010 mining volumes have been constantly decreasing (Fig. 3). Labour productivity, as a relative indicator, may vary depending on the changes in production volumes or the number of employees at the enterprise. That is, an increase in labour productivity in machine-building for the mining industry can occur due to a reduction in the number of workers in the industry while maintaining the same level of production. This actually happened in the main branches of machine building. In addition, it is known that in case of gap in the level of labour productivity between the country and leading countries, such a country can have a growth rate of labour productivity significantly higher than the same indicator of the leader country. Accordingly, a low level of labour productivity indicates incomplete use of production capacities and inefficient enterprise management or an overabundance of employees. It can be possible effect of these factors together.

Certainly, labour productivity reflects the change in the ratio of the cost of living and materialized labour. If during the production materialized labour is used more than living labour, the company has a chance to increase

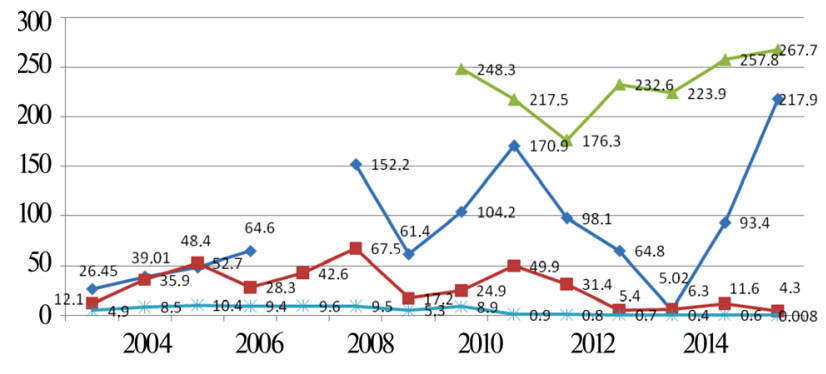

Fig. 2. Labour productivity at the machine-building enterprises of Ukraine, which produce equipment for the mining industry compared with the average labour productivity of machine-building industry:

$\rightarrow-P J S C$ "Odessa Machine-Building Plant"; $\rightarrow-$ PJSC "Odessa Production Association "Holmodmash"; $\_-$PJSC Novokramatorsk Machine Building Plant; *labor productivity in machine-building industry

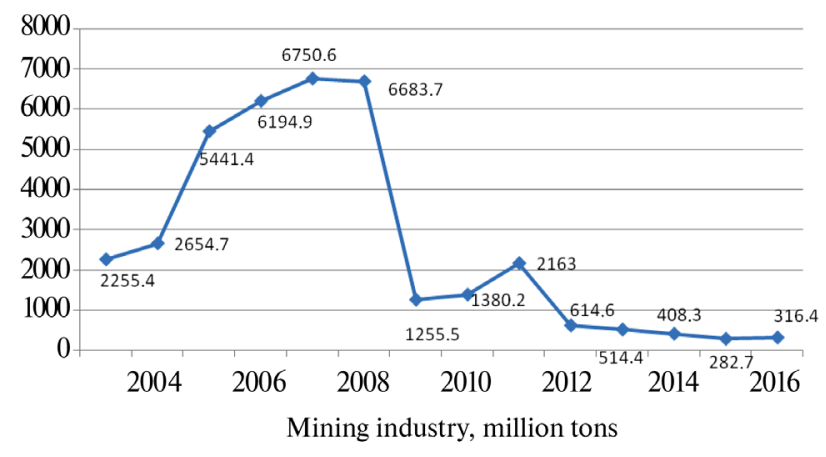

Fig. 3. Production volumes of mining industry in Ukraine 
productivity. However, there are several possible variants of the result of such an action. In one case, while reducing the cost of living labour, the spending of materialized labour per unit of output increases both in relative and in absolute terms. Otherwise, the cost of living labour increases only in relative terms, but in absolute terms it falls. Such processes can arise during automation of labour or the modernization of obsolete technology, reconstruction of enterprises based on the use of more progressive and efficient means of production are in place. An increase in production norms of additional product significantly affects the augmentation of productivity. The fact is that the profit margins are formed as a result of creating an excess of the product over the cost of work used for its creation and of the creation and accumulation of production and reserve funds due to it. All this was and remains the basis of the economic development of the enterprise.

Another way of economic development at the expense of an increase in labour productivity is the reduction of time of product circulation at the market or of logistics cycle, which is directly related to the economy of time. The savings in this case are achieved by reducing the production time, the logistics cycle and the time of market circulation of products, This is reached via the consolidation of the terms of construction and development of production capacities, prompt introduction of scientific and technological achievements into production and logistics cycle, acceleration of innovative processes and replication of best practices. As a result, having the same resources of living and materialized labour the enterprise gets higher labour productivity, which is due to an increase in the value of assets and the efficiency of the company, primarily in the sales profitability. The account of the time factor gets extremely great importance in the organization and management, especially due to high dynamism of the market economy, constant changes in the course of reform, growth and complexity of social needs. In this aspect, the study of the impact assets profitability and return on sales on the productivity of the machine-building enterprises in mining industry is an important scientific and practical task.

An interesting approach to determining the relationship between productivity and return on assets was suggested by foreign scientists O. S. Sukharev, E. M. Strizhakova [8], V. Botrić et al. [9], B. Micallef [10], who in their research proved the existence of a close interconnection between the return on assets and labour productivity. Based on this approach, we had carried out the evaluation of the impact of return of assets and return of sales on labour productivity through the calculation of correlation coefficient.

The respective estimation on the data of three machine-building enterprises of the mining industry (PJSC "Odesa Machine Building Plant", PJSC "Kholodmash" and PJSC "Novokramatorsky Machine-Building Plant") showed high and moderate correlation between respective indicators. This indicates a high degree of impact of return on assets and return on sales on productivity (Table 1).

According to Table 1, it can be seen that PJSC "Novokramatorsky Machine-Building Plant" has high correlation coefficients, which indicates a high degree of impact of the return on assets and the return on sold products on the indicator of labour productivity. PJSC "Khol-
Table 1

Correlation coefficients and impact assessment of the profitability of machine building enterprises in the mining industry on labour productivity

\begin{tabular}{|l|c|c|}
\hline $\begin{array}{l}\text { Machine building } \\
\text { enterprises for the } \\
\text { mining industry }\end{array}$ & $\begin{array}{c}\text { The value of } \\
\text { the correlation } \\
\text { coefficient } \\
\text { between } \\
\text { productivity and } \\
\text { return on assets }\end{array}$ & $\begin{array}{c}\text { The value of } \\
\text { correlation } \\
\text { coefficient } \\
\text { between labour } \\
\text { productivity } \\
\text { and return on } \\
\text { sold products }\end{array}$ \\
\hline $\begin{array}{l}\text { PJSC "Odesa } \\
\text { Machine Building } \\
\text { Plant" }\end{array}$ & -0.44 & -0.29 \\
\hline $\begin{array}{l}\text { PJSC } \\
\text { "Kholodmash" }\end{array}$ & 0.40 & 0.38 \\
\hline $\begin{array}{l}\text { PJSC } \\
\text { "Novokramatorsky } \\
\begin{array}{l}\text { Machine-Building } \\
\text { Plant" }\end{array}\end{array}$ & 0.51 & 0.70 \\
\hline
\end{tabular}

modmash" has moderate correlation coefficients, but they also indicate that the impact of these indicators on labour productivity exists. The reverse effect of the indicators is observed only at PJSC "Odesa Machine Building Plant", which testifies that labour productivity already affects profitability of the enterprise. Moreover, the estimation shows that there is a moderate impact on the return on assets. In addition, for all companies, productivity growth was observed as far as the number of employees was reducing. Thus, the greatest contribution to the growth of labour productivity is the pace of change in the number of employees, rather than an increase in production rates. Moreover, recently there has been a significant reduction in the volumes of production of machine building, including that of mining industry (Table 2).

The study of the economic content of labour productivity and the calculations made allow us to determine the following factors, which are the sources of productivity growth of the machine-building enterprises in mining industry: the degree of introduction of innovations and the use of new technologies in production; introduction of methods for improving the organization of work; an increase in the qualification of employees.

Let us consider the dynamics of changes in these factors in the industry. The statistical data confirm the cyclical dynamics of the development of innovation policy of industrial enterprises in Ukraine. While in 2002 the share of enterprises that implemented innovations was $14.6 \%$, in 2005 it decreased to $8.5 \%$; in 2012-2013, it grew to $13.6 \%$, but starting from 2014 , the share began falling, with subsequent growth to $16.6 \%$ in 2016 (Fig. 4).

In general, we can conclude that the enterprises introducing innovations represent a small share in the economy of the country.

Let us consider the enterprises that introduce new technological processes, which correspond to the indicator "implementation of methods for improving the organization of work". According to statistics, the number of Ukrainian enterprises that introduced technological 
Table 2

Key indicators used for the calculation of labour productivity for machine-building enterprises of mining industry

\begin{tabular}{|c|c|c|c|c|c|c|c|c|c|}
\hline \multirow[b]{2}{*}{ Year } & \multicolumn{3}{|c|}{$\begin{array}{l}\text { PJSC "Odesa Machine } \\
\text { Building Plant" }\end{array}$} & \multicolumn{3}{|c|}{$\begin{array}{c}\text { PJSC } \\
\text { "Kholodmash" }\end{array}$} & \multicolumn{3}{|c|}{$\begin{array}{c}\text { PJSC } \\
\text { "Novokramatorsky } \\
\text { Machine-Building } \\
\text { Plant" }\end{array}$} \\
\hline & 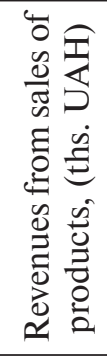 & 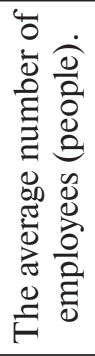 & 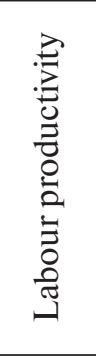 & 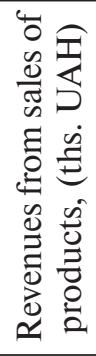 & 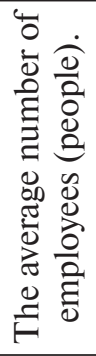 & 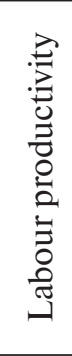 & 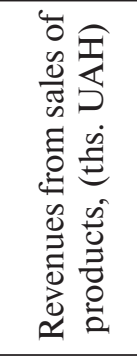 & 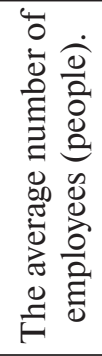 & 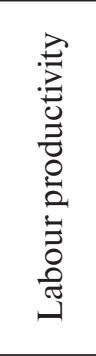 \\
\hline 2008 & 35016 & 230 & 152.2 & 12769 & 189 & 67.6 & - & - & - \\
\hline 2009 & 14124 & 230 & 61.4 & 3249 & 189 & 17.2 & - & - & - \\
\hline 2010 & 23978 & 230 & 104.2 & 4699 & 189 & 24.8 & 3427280 & 13800 & 248.3 \\
\hline 2011 & 39301 & 230 & 170.8 & 9433 & 189 & 49.9 & 2914345 & 13400 & 217.5 \\
\hline 2012 & 21784 & 222 & 98.1 & 5931 & 189 & 31.4 & 2372735 & 13460 & 176.3 \\
\hline 2013 & 14269 & 220 & 64.9 & 1016 & 189 & 5.4 & 2675465 & 11500 & 232.6 \\
\hline 2014 & 1004 & 200 & 5.0 & 1194 & 189 & 6.3 & 2574823 & 11500 & 223.9 \\
\hline 2015 & 18024 & 193 & 93.4 & 2196 & 189 & 11.6 & 2965133 & 11500 & 257.8 \\
\hline 2016 & 34207 & 157 & 217.8 & 805 & 189 & 4.3 & 3079114 & 11500 & 267.7 \\
\hline
\end{tabular}

processes increased from 1.403 in 2000 to 2.043 in 2011, and despite the economic stagnation in 2014, the number of innovative enterprises was 1.743, and already in 2015 it decreased to 1.217. However, in 2016 there was a rapid increase in this indicator to 3.489 enterprises. In Fig. 5 the

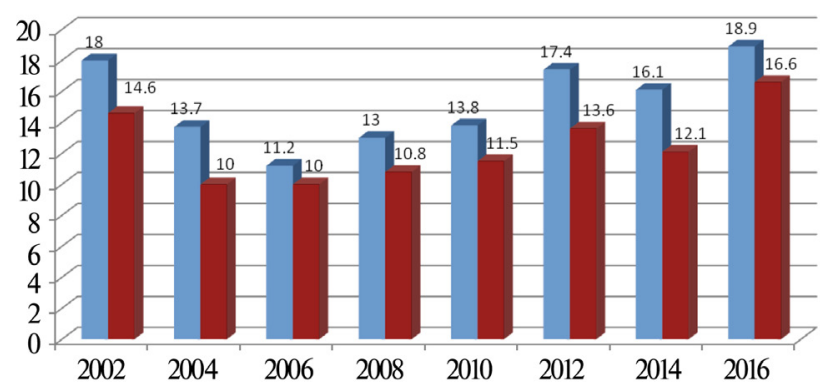

Fig. 4. Share of enterprises engaged in and implementing innovations in Ukraine [11]:

- the share of enterprises engaged in innovations, \%; share of enterprises that implemented innovations, \%

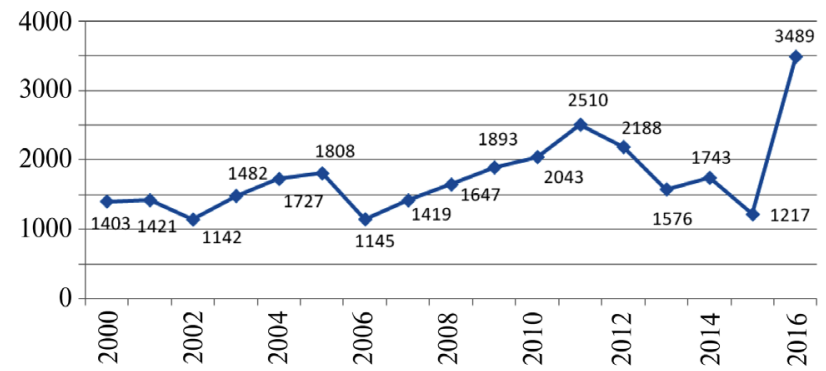

Fig. 5. The level of introduction of new technological processes in the economy of Ukraine during 2000-2016 [11] level of implementation of new technological processes in the economy of Ukraine is represented. It is also cyclical.

Despite the increase in the level of implementation of innovations, the proportion of innovative products that are produced is decreasing. In Fig. 6, the structure of innovation activity for the period from 2002 to 2016 is represented, according to the level of implementation of innovations and innovative products.

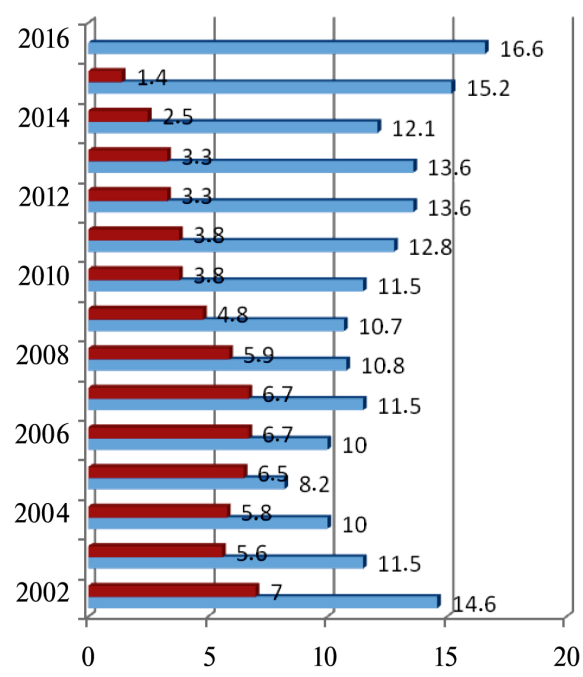

Fig. 6. The structure of innovation activity for the period 2002-2016 by the level of implementation of innovations and innovative products [11]:

- the share of realized innovative products in the volume of industrial, \%; - - share of enterprises that introduced innovations, \% 
The results of the analysis of patenting and the use of industrial property objects in Ukraine for 2008-2016 also indicate, that during this period the number of applications for the protection of inventions, utility models, industrial designs, trademarks, technologies of integrated circuits and plant varieties; in general, the activity on creation, use and commercial realization of scientific and technical products, became more active.

The third main factor influencing the rate of labour productivity is the growth of the skills of workers. However, during the period of Ukraine's independence, a decline in the prestige of engineering specialties was observed, a reduction in real wages in industry and a drop in performance indicators of enterprises were in place.

One of the main indicators of the efficiency of industrial enterprises is the ratio of growth rates of productivity and wages. In economic theory it is considered axiom that the growth rate of labour productivity should outstrip the growth of wages. Despite this, in Ukrainian practice this condition is not always followed, which is confirmed by following estimations (Fig. 7).

Based upon the information presented in Fig. 7, in the Ukrainian industry there are no real reserves at all for the increase in the average monthly wage. During 2004-2016, the labour productivity shows a downward trend, with the exception for several years. Taking into account that this data is rather relative than absolute, these few years do not affect the general trend in the industry.

Among the ways of increasing labour productivity in machine building of mining industry there should be the following:

1. Improvement of the organization of production and labour due to the formation of labour force with newest qualification; increase in productivity standards; reduction in the number of employees; prevention of personnel turnover; simplification of the management structure; mechanization of accounting and computing work; change of working period; increase in the level of production specialization.

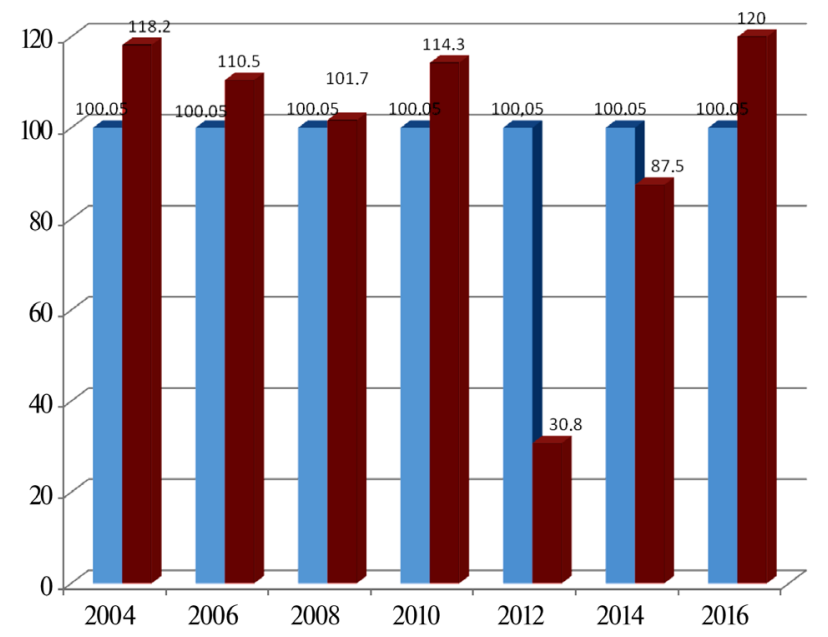

Fig. 7. The ratio of growth rates of labour productivity and wages in Ukrainian industry [11]:

- the growth rate of labor productivity in machine building enterprises; - the growth rate of average monthly wages in industry
2. Transformation of the factors of the macroeconomic environment of the enterprise, especially in the field of ecology. It is necessary to respect European experience in constructing environmental law in mining and machinebuilding enterprises in mining industry. It is necessary to take into account modern requirements regarding the environmental component of industry functioning and take it into account while calculating labour productivity in the industry.

3. Structural transformations in the field of production, aimed at modernizing fixed assets, changing the share of production technology of certain types of products, labour complexity of the production program, increasing the weight of new products.

4. Creation and development of the necessary social infrastructure, aimed at solving financial problems, timely payment of wages, formation of a social package for employees.

5. Ensuring the competitiveness of the enterprise on the basis of determining the marginal productivity of labour. This mechanism can be explained as follows. For example, an enterprise, while determining the required number of workers, should determine the price of labour demand, that is, the level of wages. According to the law of killing marginal productivity, the price of a product is formed depending on the value of the last marginal unit of the factor of production, which was used in its production. This approach proves the formation wages, which will be equal to the price of the marginal product. Thus, the enterprise will strive to balance the level of the marginal product and the wages of workers. This will encourage the involvement of such a number of workers, which will support this balance. The application of this theory in practice allows establishing reasonable prices for factors of production. If an enterprise seeks to minimize costs, the cost of factors of production will be proportional to the level of their marginal productivity. It is one of the goals of pricing policy. As a result, the company will strive to equalize the value of the marginal product and wages. This mechanism justifies the price as a factor of influence on the competitiveness of the company and its products on the market. Thus, the company's management seeks to optimize all the resources needed to produce goods under the condition of reaching the level of marginal productivity.

Proceeding from the above-mentioned provisions, it is possible to offer the competitiveness strategies to enterprises of machine building of mining industry.

For market outsiders the following areas can be identified as those increasing the company's competitiveness: reviewing the underlying competitive strategies that are used; maximizing profits by setting high prices and increasing marketing costs; reducing production costs; reducing illiquid assets; combining all these methods.

A company with a weak competitive position can improve its competitiveness on the basis of work with cheap products or by using differentiation strategies via maintaining sales volumes, market share, profitability, and specific position at existing levels. It is also possible to reinvest into the business in order to obtain short-term profits.

For companies with a high level of competitiveness and a strong competitive position one could recommend- 
ed the strategy of concentration on expanding its own capacities. For such enterprises it is also possible to adapt to a specific group of consumers or to create an innovative product. We recommend using a strategy of tracking the leader. In any case, whatever position the company occupied in any market environment, productivity growth is essential for its survival and competitiveness. This is higher productivity that has always provided and provides benefits and, finally, the victory not only for individual enterprises, their associations, industries, but also for countries.

Conclusions and recommendations for further research. As a result of the research, the factors influencing the productivity of machine-building enterprises in mining industry were substantiated and studied. The main factors that are the sources of productivity growth at the machine-building enterprises in mining industry include the following: the degree of introduction of innovations and the application of new technologies at the enterprises; introduction of methods for improving the organization of work; an increase in the level of qualification of employees. In the course of the assessment two forms of labour productivity were analysed on the example of the machine-building enterprises in the mining industry as a source of cost reduction of unit labour costs and savings of working time. The ways of increase in labour productivity in mechanical engineering for the mining industry were determined. The high degree of impact of return on assets and the return on sales on labour productivity in the machine-building enterprises in mining industry was showed through correlation analysis. It contributes to economically reasonable rate of labour productivity in terms of formation, both quantitative and qualitative indicators to measure the competitiveness of industrial products and industrial enterprises overall.

The approach to ensure the competitiveness of the enterprise based on the determination of marginal productivity is proposed and grounded. It is based on the determination of the growth of production volumes, the basis of which is the use of an additional unit of labour, other things being equal. This approach encourages enterprises to optimize resources based on the use of additional labour or the suppression of inefficient labour, thereby achieving a level of marginal productivity.

\section{References.}

1. Amosha, O., Starichenko, L. and Cherevatskii, D., 2013. Status, main problems and perspectives of the coal industry of Ukraine. Donetsk.

2. Buleev, I. P. and Brukhovetskaia, N. U., 2016. Methods for development and provision of capitalization of industrial enterprises in conditions of institutional changes. Kyiv.

3. Chuprov, S., 2016. Innovative prospects, nonlinear dynamics and the regional industry development. Journal of International Studies, 9(2), pp. 65-78.

4. Puziak, M., 2017. The Persistence of Abnormal Returns: Analysis of Polish Manufacturing Industry. Economics and Sociology, 10(1), pp. 48-60.

5. Lashenko, V.I., 2015. Ukraine XXI: Neo-industrial state or "crash of the project" ? Kyiv.

6. Dychkovskyi, R. O., Avdiushchenko, A. S., Falshtynskyi, V.S. and Saik, P. B., 2013. On the issue of estima- tion of the coal mine extraction area economic efficiency. Naukovyi Visnyk Natsionalnoho Hirnychoho Universytetu, 4, pp. 107-114.

7. Piwniak, G. G., Bondarenko, V.I., Salli, V. I., Pavlenko, I. I. and Dychkovskiy, R. O., 2007. Limits to economic viability of extraction of thin coal seams in Ukraine. Technical, Technological and Economic Aspects of Thin-Seams Coal Mining International Mining Forum 2007, pp. 129-132. DOI: $10.1201 /$ noe 0415436700.ch16.

8. Sukharev, O. S. and Strizhakova, E. N., 2017. Labour productivity in industry: the system task of management. Ekonomika I predprinimatelstvo, 8, pp. 389-402.

9. Botrić, V., Božić, Lj. and Broz, T., 2017. Explaining firm-level total factor productivity in post-transition: manufacturing vs. services sector. Journal of International Studies, 10(3), pp. 77-90.

10. Micallef, B., 2016. Determinants of Labour Productivity in Malta: Evidence from a Firm-Level Survey, Economics and Sociology, 9(4), pp. 27-40.

11. State Statistics Service of Ukraine, 2017 [online]. Available at: <http://www.ukrstat.gov.ua/ $>$ [Accessed $14 \mathrm{Au}-$ gust 2017].

Мета. Дослідження факторів впливу на продуктивність праці машинобудівних підприємств для гірничодобувної промисловості та їх оцінка з метою підвищення конкурентоспроможності. Обгрунтування напрямів посилення конкурентоспроможності підприємств машинобудування для гірничодобувної промисловості шляхом підвищення продуктивності праці. Оцінити вплив на показник продуктивності праці машинобудівних підприємств для гірничодобувної галузі показників рентабельності активів і рентабельності реалізованої продукції за допомогою кореляційного аналізу. Обгрунтувати показник продуктивності праці як базовий при формуванні кількісних і якісних показників оцінки конкурентоспроможності продукції підприємств.

Методика. У процесі дослідження використані методи аналізу й синтезу, дедукції та індукції (використовувалися під час визначення факторів, що впливають на продуктивність праці підприємства), систематизації та узагальнення (для уточнення співвідношення витрат живої й матеріалізованої праці, систематизації ключових шляхів підвищення продуктивності праці з метою посилення конкурентоспроможністю підприємства), кореляційний аналіз (при визначенні взаємозв'язку між продуктивністю праці на підприємствах машинобудування для гірничодобувної галузі й показниками рентабельності активів і рентабельності реалізованої продукції).

Результати. Досліджені та обгрунтовані фактори впливу на продуктивність праці машинобудівних підприємств для гірничодобувної промисловості. Проаналізовані форми прояву показника продуктивності праці на прикладі цих підприємств. Визначені шляхи підвищення продуктивності праці для машинобудівних підприємств у таких напрямах розвитку: поліпшення організації виробництва й праці за рахунок формування робочої сили з новою кваліфікацією; трансформація чинників макроекономічного серед- 
овища підприємства, особливо в екологічній сфері; структурні трансформації в галузі виробництва з метою модернізацію основних фондів; створення й розвитку необхідної соціальної інфраструктури; забезпечення конкурентоспроможності підприємства на основі визначення граничної продуктивності праці. Запропоновані напрями посилення конкурентоспроможності підприємства шляхом впровадження наступних заходів: перегляд базових конкурентних стратегій; збільшення доходу за рахунок підвищення цін і витрат на маркетинг; зниження витрат; скорочення неліквідних активів; комбінування всіх методів. Запропоновано забезпечувати конкурентоспроможність підприємства на основі визначення граничної продуктивності праці. Встановлено ступінь впливу на продуктивність праці підприємств машинобудування для гірничодобувної галузі показників рентабельності активів і рентабельності реалізованої продукції за допомогою кореляційного аналізу.

Наукова новизна. Економічно обгрунтовано показник продуктивності праці в аспекті формування кількісних і якісних показників оцінки конкурентоспроможності продукції промислових підприємств через комплексну дію на загальний рівень конкурентоспроможності підприємства. Запропоновано та обгрунтовано підхід до забезпечення конкурентоспроможності підприємства на основі визначення граничної продуктивності праці, що базується на визначенні зростання обсягів продукції, з використанням додаткової одиниці праці за інших фіксованих умов. Цей підхід стимулює підприємства оптимізувати ресурси на базі застосування додаткової праці або витіснення неефективної праці й досягнення рівня граничної продуктивності.

Практична значимість. Результати дослідження можуть бути використані для подальших наукових розробок у даному напрямі, а також у практичній діяльності машинобудівних підприємств як елемент підвищення конкурентоспроможності підприємства. Обгрунтовано підхід, що використовує в базисі показника продуктивності праці скорочення часу обігу продукції або логістичного циклу, що безпосередньо пов'язано з економією часу. У результаті підприємство за тих же ресурсів живої та матеріалізованої праці отримує високі показники продуктивності праці, що впливає на збільшення вартості активів і показники ефективності роботи підприємства, у першу чергу, на рентабельність реалізованої продукції

Ключові слова: машинобудування, продуктивність праці, конкурентоспроможність, рентабельність активів, рентабельність реалізованої продукції

Цель. Исследование факторов влияния на производительность труда машиностроительных предприятий для горнодобывающей промышленности и их оценка с целью повышения конкурентоспособности. Обоснование направлений повышения конкурентоспособности предприятий машиностроения для горнодобывающей промышленности с помощью увеличения уровня производительности труда. Оценить влияние на показатель производительности труда машиностроительных предприятий для горнодобывающей отрасли показателей рентабельности активов и рентабельности реализованной продукции с помощью корреляционного анализа. Обосновать показатель производительности труда, как базовый при формировании количественных и качественных показателей для оценки конкурентоспособности продукции предприятий машиностроения.

Методика. В процессе исследования использованы методы анализа и синтеза, дедукции и индукции (использовались при определении факторов, влияющих на производительность труда предприятия), систематизации и обобщения (для уточнения соотношения затрат живого и овеществленного труда, систематизации ключевых путей повышения производительности труда с целью усиления конкурентоспособности предприятия), корреляционный анализ (при определении взаимосвязи между производительностью труда на предприятиях машиностроения для горнодобывающей промышленности и показателями рентабельности активов и рентабельности реализованной продукции).

Результаты. Исследованы и обоснованы факторы влияния на производительность труда машиностроительных предприятий для горнодобывающей промышленности. Проанализированы формы проявления показателя производительности труда на примере этих предприятий. Определены пути повышения производительности труда для машиностроительных предприятий в таких направлениях развития: улучшение организации производства и труда за счет формирования рабочей силы с новой квалификацией; трансформация факторов макроэкономической среды предприятия, особенно в экологической сфере; структурные преобразования в отрасли производства с целью модернизации основных фондов; создание и развитие необходимой социальной инфраструктуры; обеспечение конкурентоспособности предприятия на основе определения предельной производительности труда. Предложены направления усиления конкурентоспособности предприятия путем внедрения следующих мероприятий: пересмотр базовых конкурентных стратегий; увеличение дохода за счет повышения цен и затрат на маркетинг; снижение затрат; сокращение неликвидных активов; комбинирование всех методов. Предложено обеспечивать конкурентоспособность предприятия на основе определения предельной производительности труда. Установлена степень влияния на производительность труда предприятий машиностроения для горнодобывающей промышленности показателей рентабельности активов и рентабельности реализованной продукции с помощью корреляционного анализа.

Научная новизна. Экономически обоснован показатель производительности труда в аспекте формирования количественных и качественных показателей оценки конкурентоспособности продукции промышленных предприятий через комплексное воздействие на общий уровень конкурентоспособности предпри- 
ятия. Предложен и обоснован подход к обеспечению конкурентоспособности предприятия на основе определения предельной производительности труда, основанной на определении роста объемов продукции с использованием дополнительной единицы труда при других фиксированных условиях. Этот подход стимулирует предприятия оптимизировать ресурсы на базе применения дополнительной работы или вытеснения неэффективной работы и достижения уровня предельной производительности.

Практическая значимость. Результаты исследования могут быть использованы для дальнейших научных разработок в данном направлении, а также в практической деятельности машиностроительных предприятий как элемент повышения конкурентоспособности предприятия, основанный на экономическом базисе показателя производительности труда.

UDC 656.2

S. M. Turpak ${ }^{1}$, Dr. Sc. (Tech.), Prof., orcid.org/0000-0003-3200-8448,

I. O. Taran ${ }^{2}$, Dr. Sc. (Tech.), Prof., orcid.org/0000-0002-3679-2519,

O. V. Fomin ${ }^{3}$, Dr. Sc. (Tech.), Assoc. Prof., orcid.org/0000-0003-2387-9946,

O. O. Tretiak ${ }^{2}$, Cand. Sc. (Tech.), Assoc. Prof., orcid.org/0000-0002-6991-0235
Обоснован подход, который использует в базисе показателя производительности труда сокращение времени оборота продукции или логистического цикла, что непосредственно связано с экономией времени. В результате предприятие при тех же ресурсах живого и овеществленного труда получает высокие показатели производительности труда, что влияет на увеличение стоимости активов и показатели эффективности работы предприятия, в первую очередь, на рентабельность реализованной продукции.

Ключевые слова: машиностроение, производительность труда, конкурентоспособность, рентабельность активов, рентабельность реализованной продукции

Рекомендовано до публікації докт. екон. наук I.В. Свиноусом. Дата надходження рукопису 09.12.17.

DOI: $10.29202 /$ nvngu/2018-1/3

1-Zaporizhzhya National Technical University, Zaporizhia, Ukraine, e-mail: turpak@i.ua

2 - National Mining University, Dnipro, Ukraine

3 - The State University of Transport Economy and Technologies, Kyiv, Ukraine

\section{LOGISTIC TECHNOLOGY TO DELIVER RAW MATERIAL FOR METALLURGICAL PRODUCTION}

С. М. Турпак ${ }^{1}$, д-р техн. наук, проф., orcid.org/0000-0003-3200-8448, I. О. Таран ${ }^{2}$, д-р техн. наук. проф., orcid.org/0000-0002-3679-2519, О. В. Фомін ${ }^{3}$, д-р техн. наук. доц., orcid.org/0000-0003-2387-9946, O. О. Третяк ${ }^{2}$, канд техн. наук. доц., orcid.org/0000-0002-6991-0235
1 -Запорізький національний технічний університет, м. Запоріжжя, Україна, e-mail: turpak@i.ua

2 - Державний вищий навчальний заклад „Національний гірничий університет“, м. Дніпро, Україна

3 - Державний економіко-технологічний університет транспорту, м. Київ, Україна

\section{ЛОГІСТИЧНА ТЕХНОЛОГІЯ ДОСТАВКИ СИРОВИНИ ДЛЯ МЕТАЛУРГІЙНОГО ВИРОБНИЦТВА}

Purpose. To formalize logistic systems and technologies concerning the management of cargo delivery in terms of metallurgical production taking into consideration interaction between motor transport and railway transport. It is required to develop a logistic technology to manage transport generalizing efficiency indices and making it possible to optimize functioning of general transportation system of an enterprise.

Methodology. System analysis and logistic approach have been used. Transportation system of an enterprise has been analyzed from the viewpoint of logistics. The analysis makes it possible to integrate efficiency indices of functioning of certain subsystems of the general micrologistic system. Objective function and general model of transportation system optimization have been determined.

Findings. Logistic technology providing optimization of the parameters of transportation system functioning according to general logistic criterion has been represented. Micrologistic systems have been singled out; tendencies to control the delivery aimed at providing functional efficiency of transportation system of an enterprise have been determined. Parameters and factors determining the parameters of transportation efficiency to the fullest extent being the basis of developing logistic transportation systems of enterprises have been identified. 